\title{
Genetic Distances of Rainbow Trout and Masu Salmon as Determined by PCR-Based Analysis
}

\author{
${ }^{\dagger} J o n g-M a n$ Yoon \\ Dept. of Aquatic Life Medicine, College of Ocean Science and Technology, Kunsan National University, Gunsan 54150, Korea
}

Received: July 17, 2020

Revised: August 31, 2020

Accepted: September 11, 2020

${ }^{+}$Corresponding author

Jong-Man Yoon

Dept. of Aquatic Life Medicine, College of

Ocean Science and Technology,

Kunsan National University, Gunsan 54150, Korea.

Tel: +82-63-469-1887

Fax: +82-63-469-1881

E-mail:jmyoon@kunsan.ac.kr

Copyright $\odot 2020$ The Korean Society of Developmental Biology.

This is an Open Access article distributed under the terms of the Creative Commons Attribution Non-Commercial License (http://creativecommons.org/licenses/ by-nc/4.0/) which permits unrestricted non-commercial use, distribution, and reproduction in any medium, provided the original work is properly cited.

ORCID

Jong-Man Yoon

https://orcid.org/0000-0003-2825-681X

Conflict of interests

The authors declare no potential conflict of interest.

\section{Acknowledgements}

The author would like to thank the referees who assisted with detailed and smart review. Precise thanks go to my undergraduate students for their maintenances for their aid in sampling, and their backings with the research of PCR analysis and statistical treatments during the course of this study processes. The author wishes to acknowledge the financial support of the Fisheries Science Institute of Kunsan National University made in the program year of 2020.

\section{Authors' contributions}

The article is prepared by a single author.

\section{Abstract}

This study used a PCR-based genetic analysis platform to create a hierarchical polar dendrogram of Euclidean genetic distances for two salmonid species, Oncorhynchus mykiss (rainbow trout, RT) and Oncorhynchus masou (masu salmon, MS). The species were distantly related to other fish species based on PCR results from using the designed oligonucleotide primer series. Five oligonucleotide primers were used to generate 330 and 234 scorable fragments in the RT and MS populations, respectively. The DNA fragments ranged in size from approximately $50 \mathrm{bp}$ to more than $2,000 \mathrm{bp}$. The bandsharing (BS) results showed that the RT population had a higher average BS value $(0.852)$ than that for the MS population (0.704). The genetic distance between individuals supported the presence of adjacent affiliation in cluster I (RT 01-RT 11). The observation of a significant genetic distance between the two Oncorhynchus species verifies that this PCR-based technique can be a useful approach for individual- and population-based biological DNA investigations. The results of this type of investigation can be useful for species safekeeping and the maintenance of salmonid populations in the mountain streams of Korea.

Keywords: Euclidean genetic distances, Masu salmon, Polar dendrogram, Rainbow trout

\section{INTRODUCTION}

Salmonids are among the most popular fish types in Korea and are a favorite food due to their taste, flavor, and nutritional value. Salmonids belong to the family Salmonidae in the order Clupeoidea and members of the genus Oncorbynchus include commercially important fish species. Salmonids are widely distributed in Alaska, Canada, Australia, New Zealand, South America, and the Far East. During the winter, salmonids are widely distributed in the cold-water streams and rivers draining steep mountains and flowing through the deep valleys of Gangwon-do and Chungcheongbuk-do provinces of the Korean peninsula.

Like other fish, growth rates of salmonids are significantly influenced by water quality. In particular, there are marked alterations of shape, color, size, and weight in salmonids according to changes in their ecological environment, such as food availability, prey type, rock mineral, water temperature, and life stage.

The classification of finfish species is based on morphological variations in various factors, such as body size, body type, body color, head shape and structure, and fin type and placement. It is assumed 
Ethics approval

This article does not require IRB/IACUC approval because there are no human and animal participants. that differences in such traits reflect a species-distinct origin and its genetic identity (Chenyambuga et al., 2004). Various features of rainbow trout (RT; Oncorbynchus mykiss) and masu salmon (MS; Oncorbynchus masou) reflect their preferred freshwater habitat, such as creeks, lakes or rivers, as well as the depth of water and type of prey.

Members of the genus Oncorbynchus are environmentally and biologically important fish in Korea. Moreover, Oncorhynchus species are renowned as being aquaculturally (Baik et al., 2007), histologically (Yoon, 2002), pathologically (Sohn et al., 1993), food nutritionally (Kim et al., 2014), and morphologically (Myoung \& Kim, 1993; Myoung \& Kim, 1996) significant. However, compared to other species, there are relatively few genetic and molecular biological studies of Oncorbynchus species in Korea. It is crucial to determine the genetic traits and relationships of Oncorbynchus species in order to assess their genetic importance correctly.

Polymerase chain reaction (PCR)-based molecular analysis approaches have been applied to study the genetic characters of various fish and crustacean species (Partis \& Wells, 1996; Tassanakajon et al., 1998; Muchmore et al., 1998; Cagigas et al., 1999; McCormack et al., 2000; Zhou et al., 2000; Yoon \& Park 2002; Islam et al., 2005; Song \& Yoon, 2013). In general, markers peculiar to a geographical population, breed, species, or genus have been applied to individuals or groups to determine genetic status, assess their hybrid parentage, or assess the usefulness of DNA markers. In this study, to clarify the Euclidean genetic distances between two salmonid species, the author carried out cluster analyses of samples of RT and MS being cultured in the Pyeongchang county of Gangwon-do province of Korea.

\section{MATERIALS AND METHODS}

DNA extraction was performed using previously described separation and extraction methods (Oh \& Yoon, 2014). Before the extraction of DNA, muscle samples were obtained from 11 individual RT and 11 from individual MS, respectively. The collected muscle was placed in sterile tubes, immediately placed in liquid nitrogen, and stored at $-79^{\circ} \mathrm{C}$ until undergoing genomic DNA extraction. After some washing, the lysis buffer I $\left(155 \mathrm{mM} \mathrm{NH}_{4} \mathrm{Cl} ; 10 \mathrm{mM} \mathrm{KHCO}_{3} ; 1 \mathrm{mM}\right.$ EDTA) was added to the samples and the mixture tubes were lightly overturned. The precipitates acquired were centrifuged and suspended with lysis buffer II $(10 \mathrm{mM}$ Tris- $\mathrm{HCl}, \mathrm{pH} 8.0 ; 10 \mathrm{mM}$ EDTA; $100 \mathrm{mM} \mathrm{NaCl} ; 0.5 \% \mathrm{SDS})$ and $15 \mu \mathrm{L}$ of proteinase $\mathrm{K}$ solution $(10 \mathrm{mg} / \mathrm{mL})$ was added. After incubation, $300 \mu \mathrm{L}$ of $3 \mathrm{M} \mathrm{NaCl}$ was added, and the mixture was softly pipetted for $5 \mathrm{~min}$. Chloroform $(600 \mu \mathrm{L})$ was added to the mixture and then upset. Chilled $70 \% \mathrm{EtOH}$ was added,

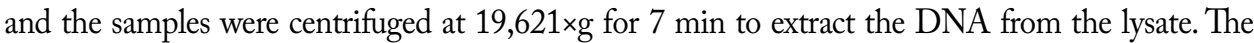
concentration of the extracted genomic DNA was calculated based on the absorbance at 260 $\mathrm{nm}$ by using a spectrophotometer (Beckman Coulter, Buckinghamshire, UK). The DNA pellets were then incubation-dried at $2{ }^{\circ} \mathrm{C}$ for overnight, held at $-79^{\circ} \mathrm{C}$, and, when needed, melted in the distilled water. The DNA augmentation was accomplished in a $25 \mu \mathrm{L}$ mixture comprised of $10 \mathrm{ng}$ of template DNA, $20 \mu \mathrm{L}$ premix (Bioneer, Daejeon, Korea), and 1.0 unit of primer. Amplification products were separated by performing electrophoresis in $1.4 \%$ agarose gels with TBE $(90 \mathrm{mM}$ Tris, $\mathrm{pH} 8.5 ; 90 \mathrm{mM}$ borate; $2.5 \mathrm{mM}$ EDTA) and using a $100 \mathrm{bp}$ DNA ladder (Bioneer) as the DNA molecular weight marker. Bands were visualized by staining with $\mathrm{EtBr}$ (Oh \& Yoon, 2014). The electrophoresed agarose gels were brightened by ultraviolet irradiation, and pictures of the gels were obtained using a Photoman Direct Copy Camera system (PECA Products, Beloit, WI, USA).

The oligonucleotide primers OPA-07 (5'-GAAACGGGTG-3'), OPA-10 (5'-GTGATCGCA G-3'), OPA-18 (5'-AGGTGACCGT-3'), OPB-07 (5'-GGTGACGCAG-3'), and OPB-20 
(5'-GGACCCTTAC-3') were obtained from Operon Technologies, USA. The use of these five primers allowed the production of bandsharing (BS) values and the calculation of genetic distances of the two salmonid species sampled. PCR was executed repeatedly by using a programmable DNA Thermal Cycler (MJ Research, Waltham, MA, USA). A similarity matrix containing the BS values of the individuals in the two sample groups was created by applying the methods described by Jeffreys and Morton (1987) and Yoke-Kqueen and Radu (2006). The intra- and inter-species Euclidean genetic distances were calculated by using the hierarchical clustering program Systat version 10 (SPSS Inc., Chicago, IL, USA). Program Systat version 10 was also utilized to acquire additional statistical analysis results such as $t$-test comparisons of means and standard errors.

\section{RESULTS AND DISCUSSION}

Five oligonucleotides primers were used to generate 330 scorable fragments for the RT and 234 scorable fragments for the MS population. The DNA fragments ranged in size from approximately $50 \mathrm{bp}$ to more than $2,000 \mathrm{bp}$ (Fig. 1). In a previous study, a phylogenetic tree was constructed using the unweighted pair group method with arithmetic mean (UPGMA) cluster analysis method to assess 3,744 distinguishable fragments in gynogenetic clones from the silver crucian carp, Carassius auratus gibelio Block (Zhou et al., 2000). In another study, the sizes of the distinguishable fragments ranged from $220 \mathrm{bp}$ to $1,700 \mathrm{bp}$ in four species of the Mullidae family (Mamuris et al., 1999). In black tiger shrimp, 80 bands ranging in size from $200 \mathrm{bp}$ to 2,200 bp were reported (Tassanakajon et al., 1998). In the brittle star (Amphiura filiformis), the DNA fragments acquired by applying four primers ranged in size from $100 \mathrm{bp}$ to 2,300 bp (McCormack et al., 2000). The use of seven oligonucleotide primers generated 317 bands in a cultured shrimp population and 385 in a wild shrimp population, and the bands ranged in size from $100 \mathrm{bp}$ to $1,800 \mathrm{bp}$ (Yoon \& Kim, 2003a). It has been reported that a single primer can generate 9 to 15 distinct bands (Tassanakajon et al., 1998). Other researchers have also examined the sizes of DNA fragments obtained using the random amplification of polymorphic DNA (RAPD) PCR-based method to genetically profile barramundi (Lates calcarifer) (Partis \& Wells, 1996), five species of Eastern Pacific abalone (genus Haliotis) (Muchmore et al., 1998), four natural Spanish populations of brown trout (Salmo trutta)

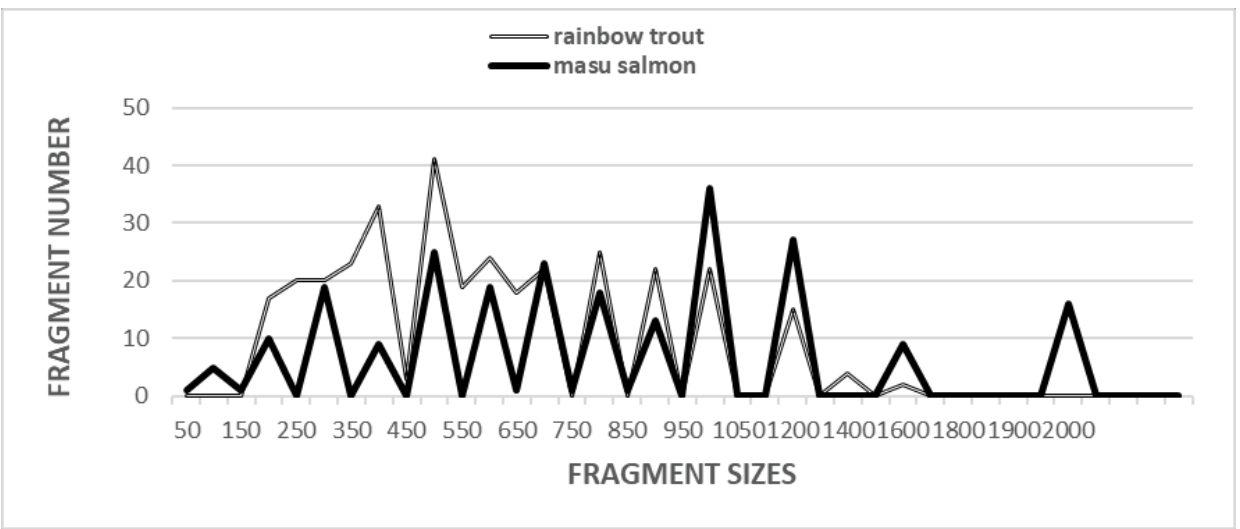

Fig. 1. Distribution of fragment sizes of rainbow trout (RT) and masu salmon (MS) species from Pyeongchang. Solid grey lines: Rt species A (RT 01, 02, 03, 04, 05, 06, 07, 08, 09, 10, and 11). Solid black lines: Ms species B (MS 12, 13, 14, 15, 16, 17, 18, 19, 20, 21, and 22). The fragment numbers in each size interval have been computed from the integrated fragments obtained with every five oligonucleotides primers. The higher fragment sizes (>2,000 bp) are observed in the MS species. 
(Cagigas et al., 1999), wild and cultured populations of crucian carp (Yoon \& Park, 2002), marsh clams (Corbicula spp.) (Yoon \& Kim, 2003b), and bastard halibut (Paralichthys olivaceus) (Yoon, 2018). Overall, specific primers have been reported to be useful for identifying individuals, with such identification based on the results obtained from examining different DNA polymorphisms (Liu et al., 1998; Park et al., 2005; Song \& Yoon, 2013).

In the present study, BS values, which are determined based on the existence or nonexistence of distinct fragments, were used to evaluate the similarity between samples of two salmonid species (Table 1). At this point, the complication of the banding patterns diverse unnaturally among the oligonucleotide primers from the two salmonid samples. The similarity matrix, which was based on the average BS value of all the samples for each of the two species, ranged from 0.756 to 0.956 among the RT samples and from 0.256 to 0.927 among the MS samples. The BS value between individual RT samples number 01 and number 02 was 0.956 , the highest value identified among the two species sampled.

The 66 unique shared loci to each species generated by the OPA- 07 oligonucleotides primer were approximately 200 bp, 350 bp, 400 bp, 500 bp, 700 bp, and 1,200 bp in size in the RT sample (Table 2). Interestingly, the oligonucleotide primer OPB-07 produced 55 unique loci shared to each species that also pinpointed each species were approximately 250 bp, 300 bp, 400 bp, 500 $\mathrm{bp}$, and $700 \mathrm{bp}$ in size in the RT sample. The primer OPB-20 generated 11 unique loci shared to each species that could be used to classify each species that were approximately 1,000 bp in size in the RT sample but interestingly, primer OPB-20 also detected 22 loci shared by the two

Table 1. Trigonal similarity matrix comprising bandsharing values assessed using Nei and Li's index of the similarity of rainbow trout (Oncorhynchus mykiss) and masu salmon (O. masou) species from Pyeongchang, respectively

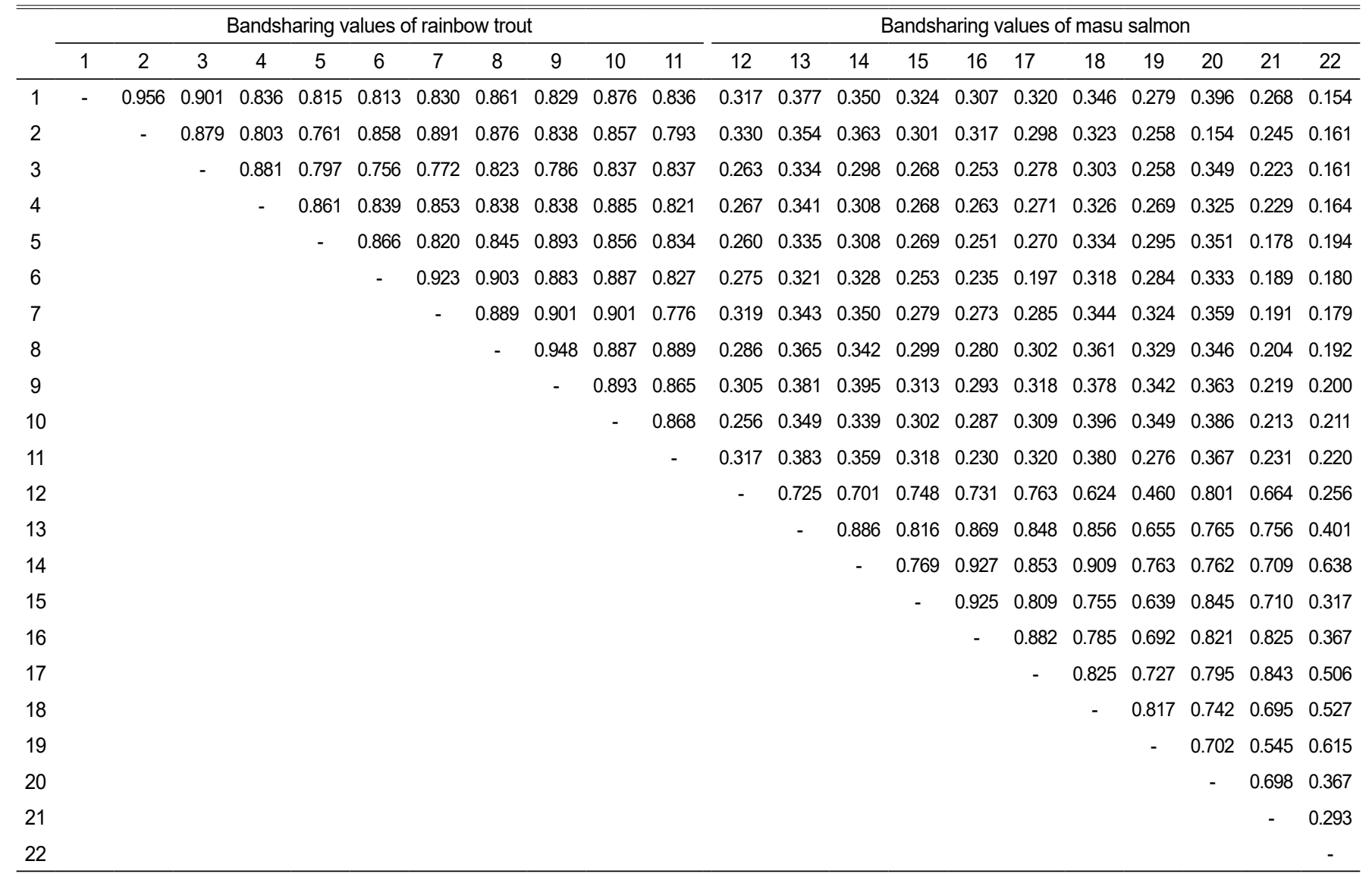


Table 2. The number of unique shared loci to each species and number of shared loci by the two salmonid species generated by DNA analysis using 5 oligonucleotides primers in rainbow trout and masu salmon from Pyeongchang of Korea

\begin{tabular}{cccc}
\hline \hline Item & No. of unique shared loci to each species & \multicolumn{2}{c}{ No. of shared loci by the two salmonid species } \\
\cline { 2 - 4 } Primer $\backslash$ species & Rainbow trout & Masu salmon & Two fish species \\
\hline OPA-07 & 66 & 0 & 0 \\
OPA-10 & 44 & 0 & 0 \\
OPA-18 & 66 & 0 & 0 \\
OPB-07 & 55 & 22 & 0 \\
OPB-20 & 11 & 22 & 22 \\
\hline Total no. & 242 & 4.4 & 22 \\
\hline Average no. per primer & 48.4 & & 4.4 \\
\hline
\end{tabular}

salmonid species. Those major and minor fragments were approximately 1,000 bp in size and were comparable in all sampled individuals of both species (Table 2).

Genetic variation within and among four natural Spanish populations of brown trout (Salmo trutta) was reported to be significantly higher based on results from microsatellite- and RAPDbased methods than from methods based on the analysis of enzyme loci (Cagigas et al., 1999). In the present study, the average BS value for individuals among the RT sample was higher (0.852) than that for individuals among the MS sample (0.704) (Table 3). The average BS values obtained in this study are similar to the values reported for Spanish barbel (0.71-0.81) (Callejas \& Ochando, 1998). The BS values between the two salmonid species in the present study also differ from those previously reported that the average bandsharing value was $0.710 \pm 0.009$ within the Korean lobster species, and 0.742 \pm 0.009 within the Indian Ocean lobster species (Park et al., 2005). However, the average $\mathrm{BS}$ value recorded in this study is higher than the average value reported for two oyster populations $(0.282 \pm 0.008)$ (Kim et al. 2004). The average BS value in this study is also higher than the average value reported for bullhead populations $(0.504 \pm 0.115)$ (Yoon \& Kim, 2004).

In the present study, the hierarchical polar dendrogram obtained by the use of five oligonucleotide primers produced two genetic clusters: cluster 1 (RT 01, 02, 03, 04, 05, 06, 07, 08, 09,10 , and 11) and cluster 2 (MS 12, 13, 14, 15, 16, 17, 18, 19, 20, 21, and 22) (Fig. 2). Within the twenty-two fish sampled, that displayed significant molecular differences, the shortest genetic distance was between individual fish no. 08 and no. 09 from cluster I (genetic distance=0.034), while the longest genetic distance among the twenty-two individuals that displayed significant molecular differences was between individual fish no. 02 and fish no. 22 (genetic distance=0.846). Comparatively, individuals within cluster I were distantly related to those in cluster II, as shown in the polar dendrogram of Euclidean genetic distances (Fig. 2). The observed genetic distances between individuals reflect the presence of individual affiliations within cluster I. The pairwise comparison values of the unbiased genetic distances between populations of Indian major carp

Table 3. Multiple calculations of average bandsharing values (mean $\pm S E$ ) between rainbow trout (Oncorhynchus mykiss) and masu salmon (O. masou) species from Pyeongchang were generated consistent with the bandsharing values and similarity matrix

\begin{tabular}{ccc}
\hline \hline Species & RT & MS \\
\hline RT & $0.852 \pm 0.006^{\mathrm{a}}$ & $0.292 \pm 0.006^{\mathrm{c}}$ \\
MS & - & $0.704 \pm 0.022^{\mathrm{b}}$ \\
\hline
\end{tabular}

a-qalues with different superscript are significantly different, $p<0.05$

Each value is a result of three different experiments.

$\mathrm{RT}$, rainbow trout; MS, masu salmon. 


\section{Cluster Tree}

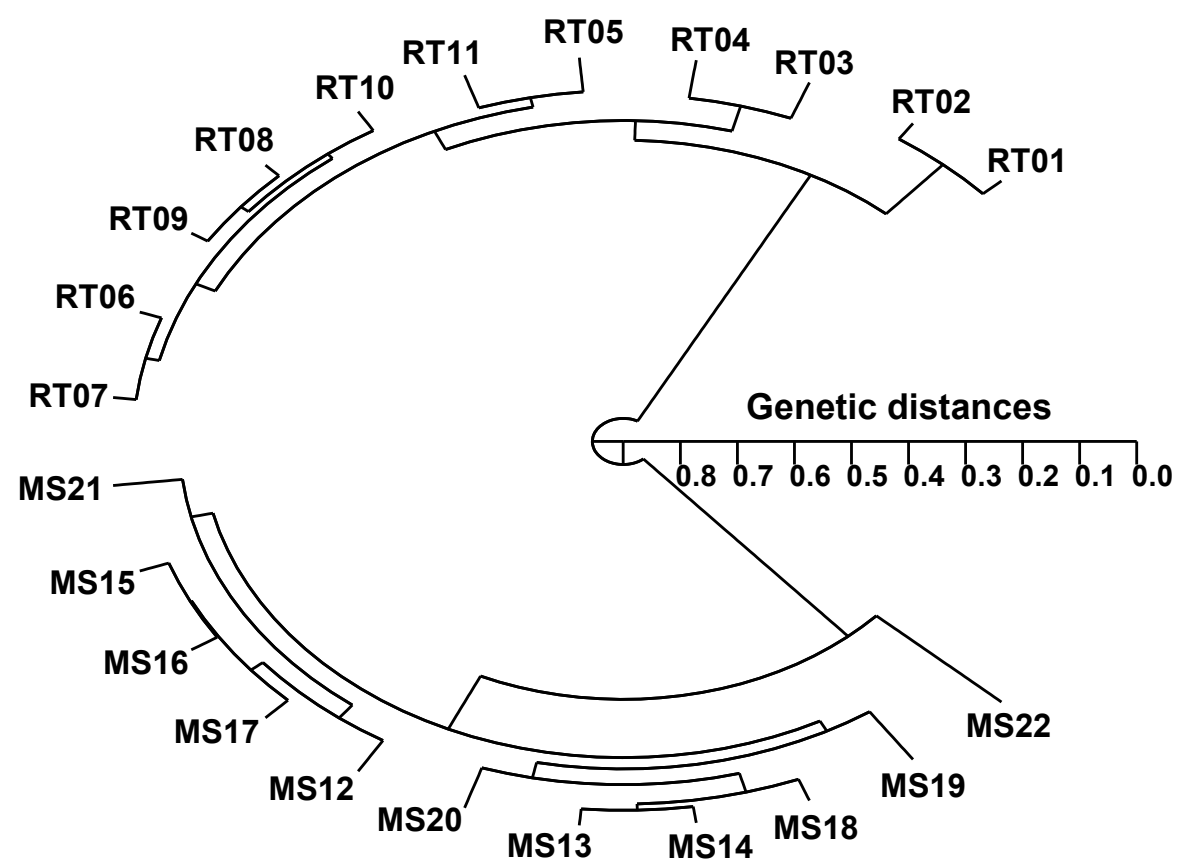

Fig. 2. Hierarchical polar dendrogram of genetic distances obtained from rainbow trout (RT) and masu salmon (MS) species. The relatedness between dissimilar individuals of RT and MS species from cluster I (RT 01, 02, 03, 04, 05, 06, 07, 08, 09, 10, and 11) and cluster II (MS 12, 13, 14, 15, 16, 17, 18, 19, 20 , 21 , and 22) generated according to the bandsharing values and similarity matrix.

(Catla catla) from the combined data for the four primers used ranged from 0.025 to 0.052 (Islam et al., 2005). Moreover, those authors reported that the Padma and Jamuna populations were separated by the lowest observed genetic distance $(\mathrm{D}=0.025)$. As mentioned, the potential of the technique used in this study to define diagnostic markers related to breed, line, species, genus, and geographic population identification in finfish (Callejas \& Ochando, 1998; Liu et al., 1998; Cagigas et al., 1999; Mamuris et al., 1999; Zhou et al., 2000; Yoon, 2018), crustaceans (Huang et al., 2000; McCormack et al., 2000; Kim et al., 2004; Song \& Yoon, 2013), and cattle (Gwakisa et al., 1994; Chenyambuga et al., 2004; Islam et al., 2005) has been established. The observation of a noteworthy genetic distance between the samples of the two Oncorbynchus species in this study has verified that a PCR-based method is an acceptable approach to DNA-based studies into the genetic identity of individuals and populations. However, further analysis using larger sample sizes and more populations and species is needed to determine the loci peculiarities of various taxa and, specifically, to assess intra- and inter-species gene flow in Oncorbynchus.

\section{REFERENCES}

Baik KK, Choi YH, Lee JC, Park IS, Kim YK, Kim DY, Lee CS (2007) Studies on seed production of rainbow trout, Oncorbynchus mykiss: Hatching rate and early stage performance of USA strain rainbow trout, Oncorbynchus mykiss. J Aqua 20:85-89.

Cagigas ME, Vazquez E, Blanco G, Sánchez JA (1999) Combined assessment of genetic variability in populations of brown trout (Salmo trutta L.) based on allozymes, microsatellites, and RAPD 
markers. Mar Biotechnol 1:286-296.

Callejas C, Ochando MD (1998) Identification of Spanish barbel species using the RAPD technique.J Fish Biol 53:208-215.

Chenyambuga SW, Hanotte O, Hirbo J, Watts PC, Kemp SJ, Kifaro GC, Gwakisa PS, Petersen PH, Rege JEO (2004) Genetic characterization of indigenous goats of sub-Saharan Africa using microsatellite DNA markers. Asian-Australas J Anim Sci 17:445-452.

Gwakisa PS, Kemp SJ, Teale AJ (1994) Characterization of zebu cattle breeds in Tanzania using random amplified polymorphic DNA markers. Anim Genet 25:89-94.

Huang BX, Peakall R, Hanna PJ (2000) Analysis of genetic structure of blacklip abalone (Haliotis rubra) populations using RAPD, minisatellite and microsatellite markers. Mar Biol 136:207216.

Islam MS, Ahmed ASI, Azam MS, Alam MS (2005) Genetic analysis of three river populations of Catla catla (HAMILTON) using randomly amplified polymorphic DNAs markers. AsianAustralas J Anim Sci 18:453-457.

Jeffreys AJ, Morton DB (1987) DNA fingerprints of dogs and cats. Anim Genet 18:1-15.

Kim JY, Park CY, Yoon JM (2004) Genetic differences and DNA polymorphism in oyster (Crassostrea spp.) analysed by RAPD-PCR. Korean J Genet 26:123-134.

Kim KH, Kang SI, Jeon YJ, Choi BD, Kim MW, Kim DS, Kim JS (2014) Food quality of rainbow trout Oncorhynchus mykiss domesticated in seawater. Korean J Fish Aquat Sci 47:114-121.

Liu Z, Li P, Argue BJ, Dunham RA (1998) Inheritance of RAPD markers in channel catfish (Ictalurus punctatus), blue catfish (I. Furcatus) and their $\mathrm{F}_{1}, \mathrm{~F}_{2}$ and backcross hybrids. Anim Genet 29:58-62.

Mamuris Z, Stamatis C, Bani M, Triantaphyllidis C (1999) Taxonomic relationships between four species of the Mullidae family revealed by three genetic methods: Allozymes, random amplified polymorphic DNA and mitochondrial DNA.J Fish Biol 55:572-587.

McCormack GC, Powell R, Keegan B (2000) Comparative analysis of two populations of the brittle star Amphiura filiformis (Echinodermata: Ophiuroidae) with different life history strategies using RAPD markers. Mar Biotechnol 2:100-106.

Muchmore ME, Moy GW, Swanson WJ, Vacquier VD (1998) Direct sequencing of genomic DNA for characterization of a satellite DNA in five species of Eastern Pacific abalone. Mol Mar Biol Biotech 7:1-6.

Myoung JG, Kim YU (1993) Morphological study of Oncorhynchus spp. (Pisces: Salmonidae) in Korea- IV. Comparison of morphological characters of chum salmon $O$. keta, masu salmon $O$. masou and rainbow trout $O$. mykiss. Korean J Ichthyol 5:96-112.

Myoung JG, Kim YU (1996) Morphological study of Oncorbynchus spp. in Korea- V. Comparison of skeletal characters of chum salmon $O$. keta, masu salmon $O$. masou and rainbow trout $O$. mykiss. J Korean Fish Soc 29:208-229.

Oh H, Yoon JM (2014) Genetic distances of three mollusk species investigated by PCR analysis. Dev Reprod 18:43-49.

Park SY, Park JS, Yoon JM (2005) Genetic differences and variations in slipper lobster (Ibacus ciliatus) and deep sea lobster (Puerulus sewelli) determined by RAPD analysis. Korean J Genet 25:307-317.

Partis L, Wells RJ (1996) Identification of fish species using random amplified polymorphic DNA (RAPD). Mol Cell Probes 10:435-441.

Sohn SG, Park MA, Park JW (1993) Studies on viral disease of masu salmon, Oncorbynchus masouII Isolation of infectious hematopoietic necrosis virus from masu salmon fry. J Fish Pathol 6:87-92. 
Song YJ, Yoon JM (2013) Genetic differences of three Pollicipes mitella population identified by PCR analysis. Dev Reprod 17:199-205.

Tassanakajon A, Pongsomboon S, Jarayabhand P, Klinbunga S, Boonsaeng V (1998) Genetic structure in wild populations of black tiger shrimp (Penaeus monodon) using randomly amplified polymorphic DNA analysis. J Mar Biotechnol 6:249-254.

Yoke-Kqueen C, Radu S (2006) Random amplified polymorphic DNA analysis of genetically modified organisms.J Biotechnol 127:161-166.

Yoon JM (2002) Ultrastructural change of osmoregulatory cells during seawater adaptation in rainbow trout (Oncorhynchus mykiss). Korean J Ichthyol 12:111-117.

Yoon JM (2018) Genetic distances of Paralichthys olivaceus populations investigated by PCR. Dev Reprod 22:283-288.

Yoon JM, Kim GW (2003a) Genetic differences between cultured and wild penaeid shrimp (Penaeus chinensis) populations analysed by RAPD-PCR. Korean J Genet 25:21-32.

Yoon JM, Kim YH (2003b) Wide marsh clam (Corbicula spp) populations from three sites analysed by RAPD-PCR-AGE. Bull Electrochem 19:337-348.

Yoon JM, Park HY (2002) Genetic similarity and variation in the cultured and wild crucian carp (Carassius carassius) estimated with random amplified polymorphic DNA. Asian-Australas J Anim Sci 15:470-476.

Yoon JM, Kim JY (2004) Genetic differences within and between populations of Korean catfish (S. asotus) and bullhead (P. fulvidraco) analysed by RAPD-PCR. Asian-Australas J Anim Sci 17:1053-1061.

Zhou L, Wang Y, Gui JF (2000) Analysis of genetic heterogeneity among five gynogenetic clones of silver crucian carp, Carassius auratus gibelio Bloch, based on detection of RAPD molecular markers. Cytogenet Cell Genet 88:133-139. 